\title{
Manfaat Vitamin D untuk Pemain Sepak Bola : Mini Literature Review
}

\author{
Gaung Perwira Yustika ${ }^{1}$, Eko Budi Santoso ${ }^{1}$, Cholichul Hadi ${ }^{2}$, Sri Sumartiningsih ${ }^{3}$ \\ ${ }^{1}$ Sekolah Tinggi Ilmu Kesehatan Surabaya, Indonesia \\ ${ }^{2}$ Universitas Airlangga, Indonesia \\ ${ }^{3}$ Universitas Negeri Semarang, Indonesia
}

Diterima: 10 Maret 2019. Direvisi: 12 September 2019. Disetujui: 02 Juli 2020

\begin{abstract}
ABSTRAK Permainan sepakbola dicirikan dengan pola aktivitas yang berubah-ubah, olahraga dengan durasi yang panjang dengan intensitas yang tinggi dan aksi yang eksplosif seperti melakukan akselarasi, deakselarasi, merubah arah, melompat, dan menjegal yang tentunya memerlukan kerja yang tinggi dari daya tubuh. Di dalam pertandingan kebutuhan energi sangat tinggi, dipenuhi dengan metabolisme aerob dan anaerob, yang mana perlu dibarengi dengan asupan nutrisi berkualitas dalam bentuk mikronutrisi khususnya asupan/pemaparan vitamin D untuk pemain agar dapat menunjang dan menjaga performa permainan dari seorang pemain, terlebih pada level sepakbola elit. Vitamin D sendiri adalah suatu prekursor hormon yang memiliki peranan penting di dalam menjaga kesehatan tulang dan fungsi imunitas. Penemuan reseptor vitamin D pada sel otot rangka manusia telah membawa para ilmuwan fisiologi otot untuk menemukan peranan penting vitamin $\mathrm{D}$ dalam meregulasikan sintesis protein dan fungsi otot. Pada atlit sepakbola elit, terdapat kebutuhan konstan vitamin D di dalam memaksimalkan sintesis protein untuk memenuhi kebutuhan fisik dari latihan harian. Selain dari pemaparan sinar matahari vitamin D pun dapat didapatkan dari sumber makanan yang mengandung nutrisi ini (hewani dan nabati).
\end{abstract}

Kata kunci: sepakbola, vitamin D, sintesis protein, imunitas.

\footnotetext{
ABSTRACT Soccer was characterized with activity that changed periodically during the game, this sport has long duration and with high intensity dan explosive action like doing acceleration, deacceleration, changing direction, jumping, and tackling. Of course in order to doing that this sport needs high rate of physical performance of the players. In the match, energy requirements is very high, fulfill by aerob metabolism and anaerob, to help the metabolism regulation, micronutrien intake especially vitamin D intake/exposure for the players to support and maintain performance of soccer players, especially in the elite level. Vitamin D is a hormonal precursor that hold an important role to maintain bone heal th and imunity function. The discovery of vitamin $D$ receptor in human skeletal's cells made attention to Muscle Physiologyst in order to find a way how vitamin D regulated protein synsthesis and muscle function. For soccer elite athletes, there's constant needs of vitamin $D$ to built synthesis protein in order to support the physical requirements from daily training. Besides sunlight exposure, vitamin D can be acquired from dietary foods that contain this vitamin (animal and plant source).
}

Keywords : soccer, vitamin D, protein synsthesis, immunity.

\section{PENDAHULUAN}

Penulis memiliki passion di bidang sepakbola, sepakbola adalah olahraga yang dicintai oleh kebanyakan masyarakat Indonesia. Permainan sepakbola dicirikan dengan pola aktivitas yang berubah-ubah, olahraga dengan durasi yang panjang dengan intensitas yang tinggi dan aksi yang eksplosif seperti melakukan akselarasi, deakselarasi, merubah arah, melompat, dan menjegal yang tentunya memerlukan kerja yang tinggi dari daya tubuh (Varley dan Aughey, 2012). Di dalam pertandingan kebutuhan energi sangat tinggi, dipenuhi dengan metabolisme aerob dan anaerob (Krustrup et al., 2006), yang mana perlu dibarengi dengan asupan nutrisi berkualitas untuk pemain agar dapat menunjang dan menjaga performa permainan dari seorang pemain, terlebih pada level sepakbola elit.

Pada artikel review ini penulis membahas manfaat terkait mikronutrien vitamin D yang dapat menunjang performa pemain sepakbola. Vitamin secara umum adalah komponen vital untuk perbaikan jaringan otot saat waktu pemulihan pada pemain sepakbola (FIFA, 2010). Vitamin juga dapat membantu pertumbuhan, menjaga kesehatan, dan penting di dalam proses metabolisme, pembuatan energi, membantu fungsi proses persarafan, dan pencegahan dari degradasi sel dan penghancuran tubuh (Kreider et al., 2010). Mikronutrien ini menjadi fundamental dalam struktur komponen dari jaringan dan sebagai pembentuk enzim dan hormon (FIFA, 2010). Mereka juga membantu pengaturan metabolisme 
dan proses persarafan (Kreider et al., 2010). Panduan rekomendasi asupan dapat dengan mudah dijalankan ketika para pemain menjalani diet gizi seimbang. Hanya para pemain yang sedang di dalam kondisi khusus membatasi asupan energi total yang masuk seperti ingin menurunkan berat badan yang tidak dianjurkan asupan mikronutrien ini (Maughan dan Shirreffs, 2007; MacLaren, 2003). Mengkonsumsinya secara berlebihan pun tidak dapat meningkatkan performa pemain, sehingga pemberiannya pun harus diberikan secara tepat (Kreider et al. 2010). Pada pembahasan kali ini akan dibahas lebih lanjut terkait manfaat vitamin D terhadap peningkatan performa pemain sepakbola.

Vitamin D sendiri adalah suatu prekursor hormon yang memiliki peranan penting di dalam menjaga kesehatan tulang dan fungsi imun (Larson-Meyer dan Willis, 2010). Penemuan reseptor vitamin D pada sel otot rangka manusia (Bischoff-Ferrari et al., 2004) telah membawa para ilmuwan fisiologi otot untuk menemukan peranan penting vitamin $\mathrm{D}$ dalam meregulasikan sintesis protein dan fungsi otot (Hamilton, 2010). Pada atlet elit, terdapat kebutuhan konstan di dalam memaksimalkan sintesis protein untuk memenuhi kebutuhan fisik dari latihan harian (Larson-Meyer dan Willis 2010; Willis et al., 2008). Bagaimanapun, peranan vitamin $\mathrm{D}$ dalam menunjang fungsi otot tidak dapat dilihat ketika musim dingin berlangsung, saat ketika pemaparan radiasi ultraviolet B sedang berkurang. Sehingga stimulus untuk prekursor utama yang mencetuskan sintesis vitamin D pun sedang berkurang (Chen et al., 2007). Selain dari pemaparan sinar matahari vitamin D pun dapat didapatkan dari sumber makanan yang mengandung nutrisi ini (hewani dan nabati).

Artikel review literature ini ditujukan untuk memberikan update informasi terkait pentingnya vitamin D untuk menunjang performa pemain sepakbola profesional, khususnya untuk memajukan sport science di negara penulis (Indonesia) dimana informasi terkait pentingnya mikronutrien khususnya vitamin D untuk pemain sepakbola belum pernah dipublikasikan. Dan juga prestasi Indonesia di bidang sepakbola di kancah persepakbolaan dunia harus dikembangkan dimulai dari sport science khususnya pada paper ini dimulai dari sport nutrition.

\section{METODE}

Bagaimana aspek-aspek terkait aspek nutrisi terkait dalam penunjangan performa untuk pemain sepakbola khususnya di level profesional, lebih khususnya lagi di Indonesia, belum banyak publikasi terkait aspek nutrisi vitamin D dalam hal ini lebih spesifiknya lagi untuk pemain sepakbola. Dengan artikel literature review yang dirangkum dari artikel-artikel ilmiah yang didapat dari media search engine: researchgate, google scholar, cross mark dan cogent medicine terkait aspek nutrisi spesifik dengan kata kunci pencarian "vitamin D soccer" ditemukanlah karya-karya tulis ilmiah yang terkait topik ini dan dengan tulisan ini diharapkan para pihak yang terkait mendapatkan pengetahuan yang penting sehingga dapat mencegah kejadian kekurangan nutrisi dalam hal ini vitamin $\mathrm{D}$ yang masif pada pemain sepakbola akibat dari ketidaktahuan pentingnya asupan nutrisi vitamin D ini bagi pemain sepakbola yang berujung pada penurunan performa. Diharapakan dengan adanya karya tulis ilmiah ini dapat mengoptimalisasi potensi pemain khususnya pada penambahan ilmu untuk para pihak staf terkait, pemain sepakbola profesional maupun amatir, muda maupun dewasa agar tidak terhambatnya prestasi pemain yang akan berujung pada penurunan prestasi sepakbola suatu negara (yang diakibatkan oleh minimnya ilmu gizi yang kita miliki).

\section{PEMBAHASAN}

Vitamin D dapat didapatkan baik dari sumber pangan atau dari pembuatan di dalam lapisan epidermis kulit yang terpapar sinar matahari. Dua bentuk vitamin D yang dapat ditemukan dari sumber makanan adalah vitamin $\mathrm{D}_{3}$ (cholecalciferol) dan vitamin $\mathrm{D}_{2}$ (ergocalciferol). Vitamin $\mathrm{D}_{3}$ umumnya ditemukan dari makanan hewani, seperti ikan salmon and kuning telur, sementara vitamin $\mathrm{D}_{2}$ didapatkan dari sumber tumbuhan dan juga jamur. Produksi vitamin $\mathrm{D}_{3}$ yang bersumber dari pemamparan ultraviolet-memediasikan perubahan dari 7-dehydrocholesterol di dalam membran plasma dari sel kulit, menyediakan $80-100 \%$ kebutuhan tubuh untuk nutrisi ini (Lanteri, Lombardi, Colombini, \& Banfi, 2013). Sintesis vitamin $\mathrm{D}_{3}$ yang berlangsung di dalam tubuh dari pemaparan sinar matahari dan sumber makanan $\mathrm{D}_{2}$ dan $\mathrm{D}_{3}$ pertama kali akan di hidroksilasi di dalam hati menjadi 25-hydroxy 
vitamin D $(25(\mathrm{OH}) \mathrm{D})$, bentuk utama yang disimpan seprti yang dilihat pada gambar 1 .

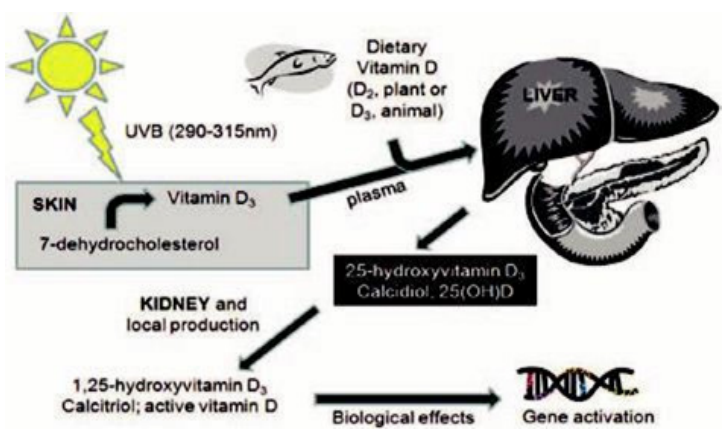

Gambar 1. Penyimpanan vitamin D di dalam hati dan bentuk aktif vitamin $\mathrm{D}$ di dalam ginjal (Angeline et al., 2013)

Pada tahap kedua hidroksilasi kemudian secara biologis akan berubah menjadi bentuk yang aktif 1,25-dihydroxy vitamin D, 1 - $\alpha$-hydroxylase di dalam ginjal dan sejumlah sel di bagian non ginjal, seperti sel-sel yang menyusun sistem imunitas diantaranya sel $\mathrm{T}$, sel B, makrofag dan sel dendritik (Aranow, 2011).

Telah diketahui bahwa peranan utama vitamin $\mathrm{D}$ menjadi mediator utama respon imunitas memacu bahan-bahan anti mikroba seperti monosit dan makrofag (Bikle, 2009). Vitamin D adalah kunci utama penghubung aktivasi reseptor pengenal mikroba dan respon akti mikroba di dalam sistem imunitas. Setelah reseptor mikroba ini mengenali keberadaan mikroba, vitamin $\mathrm{D}$ memiliki peranan utama di dalam produksi protein anti mikroba, seperti cathelicidin dan $\beta$-defensin (Liu et al., 2006). Bahan biologi yang aktif dalam bentuk 1,25-dihydroxy vitamin D terikat kepada reseptor vitamin D menginduksi ekspresi gen responsif vitamin $D$ untuk memacu produksi dari cathelicidin and $\beta$-defensin (Wang et al., 2004). Protein anti mikroba ini memiliki aktivitas pengenalan yang luas untuk menghadapi mikroorganisme dan terlibat tidak langsung dalam proses inaktivasi virus lewat mekanisme destabilisasi membran virus (Kamen dan Tangpricha, 2010). Protein ini diproduksi oleh sel epitel dan makrofag di dalam paru-paru dan disekresikan ke bagian dalam permukaan jalur pernafasan, disana mereka membentuk pertahanan yang bersifat mematikan untuk mikroba.

Vitamin D memainkan peranan penting di dalam metabolisme tulang dan fungsi normal dari sistem otot. Penyebab utama berkurangnya kadar vitamin D di dalam tubuh adalah karena kurangnya pemaparan terhadap sinar matahari dan kurangnya asupan makanan yang mengandung vitamin D (Holick, 2007). Peranan vitamin D aktif untuk keseimbangan kalsium-fosfor dan pengaruhnya terhadap metabolisme tulang telah diketahui dari 100 tahun yang lalu (Wolf, 2004). Efek proliferatif dari vitamin ini dapat diketahui setelah penemuan reseptor inti (nuclear receptor). Reseptor ini terdapat pada beberapa organ yang tersimpan di dalam sistem rangka, seperti ginjal, jantung, otak, pankreas, usus, otot dan juga kulit (Bikle, 2009). Telah dikonfirmasi bahwa vitamin D memainkan peranan penting di dalam proses imunologi, membantu proses antiinflamasi, anti-apoptosis, anti fibrinolitik, dan bahkan antitumor (Lai dan Fang, 2013).

Pengaruh vitamin D di dalam banyak proses kehidupan dan fungsi organ menarik perhatian para ilmuwan untuk meneliti aplikasinya terhadap pencegahan atau pengobatan dari suatu penyakit pada orang tua atau orang yang sedang sakit (Kestenbaum et al., 2011). Beberapa penelitian terkait difokuskan kepada orang yang masih muda, sehat dan secara fisik aktif. Penelitian sebelumnya menjelaskan terdapat hubungan vitamin D pada kerja otot rangka (Girgis et al., 2014; Stockton et al., 2011; Ostrowski et al., 2012), metabolisme tulang (Solarz et al., 2014), dan resiko cedera (Medina et al., 2014; Czuba et al., 2014; Lehnert et al., 2018).

Beberapa bukti lain menyebutkan pengaruh vitamin $\mathrm{D}$ terhadap meningkatnya fungsi muskuloskeletal pada wanita dewasa (Foo et al., 2009; Ward et al., 2009) dan populasi masyarakat yang sudah tua (Bischoff-Ferrari et al.,2004; Broe et al. 2007). Data ini mungkin ada hubungannya dengan peranan vitamin $\mathrm{D}$ untuk mengatur regulasi sintesis protein dan pertumbuhan otot melalui interaksi ekspresi reseptor vitamin $\mathrm{D}$ di dalam sel otot rangka (Bischoff-Ferrari et al. 2004) dan besar kemungkinan peranan jalur insulin-like growth factor 1 mediated pathway (Soliman et al., 2008). Datadata yang dijabarkan diatas menunjukkan pentingnya vitamin $\mathrm{D}$ ternyata tidak hanya bermanfaat untuk para olahragawan namun juga pada khalayak umum baik pria maupun wanita.

\section{Manfaat vitamin D untuk atlet umum dan se- pakbola}

Tenforde et al. (2016) memaparkan pentingnya vitamin D bagi otot untuk berfungsi optimal dan mencegah fraktur tulang akibat 
digunakan terlalu berlebihan, resiko yang sering harus dihadapi atlit elit di dalam kompetisi yang padat dan keras. Cedera yang biasa terjadi pada atlit muda dapat disebabkan oleh defisiensi vitamin D yang terkait aktivitas fisik yang berat, ditambah lagi pemaparan vitamin D ke kulit dari sinar matahari yang kurang (Farrokhyar et al., 2015).

Belum ditemukannya bukti yang jelas terkait vitamin D yang dapat meningkatkan kapasitas fisik pada atlit level elite. Studi terkait isu ini telah dilakukan pada para atlit di beberapa disiplin olahraga. Stockton et al. (2011) melakukan literature review terkait topik ini dan menemukan efektifitas yang tinggi dari suplementasi vitamin D terhadap kekuatan otot pada atlit judo, dayung, pemain hoki, dan para atlit dansa. Girgis et al. (2014) mempelajari terkait efek 8 bulan pemberian supmentasi vitamin D terhadap kapasitas fisik, efektifitas kerja otot dan perubahan pada kadar insulin pada subyek yang sehat.

Sementara penelitian lain pada tahun 2014 menunjukkan adanya hubungan kadar vitamin D di dalam tubuh para pemain sepakbola profesional dikorelasikan dengan performa aktivitas latihan (Nikolaos et al., 2014). Hubungan antara kadar vitamin $\mathrm{D}$ dan parameter performa latihan, selama awal dan akhir dari 6 minggu periode transisi, dapat dilihat pada tabel 1. Analisis menunjukkan korelasi positif antara kadar vitamin D dengan squat jump, counter movement jump dan nilai $\mathrm{VO}_{2}$ max pada awal dan akhir periode eksperimen. Sementara korelasi negatif diobservasi diantara kadar vitamin D dengan sprint $10 \mathrm{~m}$, dan $20 \mathrm{~m}$ pada awal dan akhir studi, menunjukkan hubungan negatif antara kedua variabel tersebut terhadap vitamin D. Atribut-atribut ini adalah kemampuan fisik yang utama pada pemain sepakbola seperti sprint pendek $(10 \mathrm{~m} / 20 \mathrm{~m})$ yang dilakukan untuk meninggalkan/mendahului lawan. Begitu pula tidak kalah penting kemampuan meloncat lebih tinggi untuk me- nyundul bola sehingga kemungkinan mencetak gol lebih tinggi terutama saat insiden tendangan bebas maupun penjuru atau di situasi open play. Dan terakhir terkait $\mathrm{VO}_{2}$ max yang dominan menjadi aspek penting olahraga sepakbola yang merupakan olahraga aerobik dominan. Dengan tingkat $\mathrm{VO}_{2}$ max yang lebih baik para pemain pun akan dapat menjalankan pertandingan 90 menit dibandingkan dengan lawan yang rata-rata kadar kapasitas aerobiknya lebih buruk misalnya. Dengan kapasitas aerobik yang buruk para pemain akan mengalami masalah di penghujung pertandingan seperti pada menit 70-90 dimana banyak terjadi gol conceded di gawang tim yang kehilangan konsentrasi. Hal ini juga terjadi akibat kondisi kelelahan pemain sehingga gol lebih mudah terjadi.

Ada sejumlah kemungkinan kadar $25(\mathrm{OH}) \mathrm{D}_{3}$ mempengaruhi kapabilitas (atribuk fisik dan teknis) dari seorang atlet sepakbola. Sejumlah penelitian telah menunjukkan hubungan kadar vitamin D dengan struktur dan kekuatan otot (Wicherts et al., 2007; Mowe et al., 1999; Houston et al., 2007; Bischoff - Ferrari et al., 2004; Bischoff et al., 1999). Visser et al. (2003) menjelaskan kadar $25(\mathrm{OH}) \mathrm{D}_{3}$ sekitar 30 $\mathrm{ng} / \mathrm{ml}$ menjanjikan fungsi optimal dari otot. Close et al. (2013) melaporkan data penurunan kadar vitamin D adalah salah satu penyebab penting penurunan kemampuan dari para atlet. Efek ergogenik dari vitamin D ini berhubungan dengan regulasi dari sintesis protein otot yang terbuat karena keberadaan reseptor vitamin D pada sel otot rangka (Bischoff - Ferrari et al., 2004).

Bagaimanapun penelitian lanjutan terkait vitamin D terhadap performa atlit khusunya pemain sepakbola masih harus dilakukan dengan skala dan pendanaan yang lebih besar dikarenakan impaknya yang masih unclear, sehingga dibutuhkan penelitian lanjutan terkait hal ini.

Tabel 1. Hubungan koifisien relasi dan nilai-p diantara kadar vitamin D dan parameter performa latihan (Nikolaos et al., 2014)

\begin{tabular}{lccc}
\hline Performa latihan & Pre Vitamin D $(\mathrm{ng} / \mathrm{ml})$ & Post Vitamin D $(\mathrm{ng} / \mathrm{ml})$ \\
\hline Squat Jump $(\mathrm{cm})$ & $0.731(\mathrm{p}, 0.001)$ & 0.597 & $(\mathrm{p}, 0.001)$ \\
Counter movement jump $(\mathrm{cm})$ & $0.740(\mathrm{p}, 0.001)$ & 0.476 & $(\mathrm{p}, 0.001)$ \\
$\mathrm{VO}_{2} \max (\mathrm{ml} / \mathrm{kg} / \mathrm{min})$ & $0.436(\mathrm{p}, 0.001)$ & 0.394 & $(\mathrm{p}=0.006)$ \\
$10 \mathrm{~m}($ detik $)$ & $20.649 \quad(\mathrm{p}, 0.001)$ & $20.410(\mathrm{p}, 0.001)$ \\
$20 \mathrm{~m}(\mathrm{sec})$ & $20.673 \quad(\mathrm{p}, 0.001)$ & $20.426(\mathrm{p}, 0.001)$ \\
\hline
\end{tabular}

Pre: pengukuran dilakukan pada awal saat libur musim, periode transisi; Post : pengukuran dilakukan pada akhir libur musim, periode transisi. 


\section{Defisiensi vitamin $\mathrm{D}$ pemain sepakbola}

Kekurangan vitamin D dilaporkan umum terjadi pada atlet sepakbola profesional di Inggris Raya, khususnya pada saat latihan berlangsung pada musim dingin (Close et al., 2013; He et al., 2013; Morton et al., 2012), dimana pemaparan terhadap sinar matahari sedang tereduksi. Dua penelitian yang mencoba mencari status vitamin D di dalam tubuh atlet profesional menyajikan sebagian data dari atlit meliputi pemain sepakbola profesional memiliki konsentrasi kadar serum total $25(\mathrm{OH})$ $\mathrm{D}(<50 \mathrm{nmol} / \mathrm{L})$ pada musim dingin (Close et al., 2013) dan $65 \%$ pemain sepakbola elit di Liga Primer Inggris memiliki kadar konsentrasi serum total $25(\mathrm{OH}) \mathrm{D}<50 \mathrm{nmol} / \mathrm{L}$ di bulan Desember (Morton et al., 2012). Di penelitian lain pada atlit dengan karakteristik olahraga endurance, tersaji data 55\% dari atlit (100/181) dengan kadar konsentrasi serum total $25(\mathrm{OH})$ $\mathrm{D}<50 \mathrm{nmol} / \mathrm{L}$ di ujung bulan ke 4 periodesasi latihan di musim dingin (He et al., 2013). Dengan tersajinya data kekurangan vitamin D pada atlit di Inggris Raya saat memasuki musim dingin, suplementasi vitamin $\mathrm{D}$ menjadi penting untuk meningkatkan konsentrasi vitamin D, mengingat regulasi dari protein anti mikroba yang dicetuskan vitamin D dapat mereduksi resiko infeksi saluran pernapasan yang umum terjadi pada musim dingin. Mengingat akan padatnya jadwal pertandingan kompetitif yang dilaksanakan pada periode boxing day dan ditambah lagi kompetisi piala Afrika/Asia yang biasa dilaksanakan saat musim dingin liga Eropa sehingga akan sangat disayangkan pertandingan-pertandingan yang dilewatkan pemain-pemain profesional Asia/Eropa yang bermain untuk klub Eropa akibat undernutrition vitamin $\mathrm{D}$ ini.

Morton et al. (2012) memaparkan adanya reduksi kadar serum $25(\mathrm{OH}) \mathrm{D}_{3}$ pada pemain sepakbola profesional yang bermain pada Liga Primer Inggris pada bulan Agustus dan
Desember. Hasil temuan serupa didapatkan pada pemain profesional spanyol yang berlatih pada bulan Oktober dan Februari menunjukkan pengurangan pada kadar serum (Galan et al., 2012). Hasil serupa didapatkan penurunan yang signifikan dari vitamin D tubuh pada penelitian yang dilakukan pada bulan September 2011 dan April 2012 pada pemain sepakbola profesional di Polandia (Aleksandra Kopeć et al., 2013). Perbedaan ini dapat terjadi diakibatkan kondisi iklim lingkungan yang berbeda pada periode tersebut menyebabkan adanya reduksi yang cukup signifikan yang ditemukan pada bulan april. Biasanya pada bulan april adalah periode yang cukup sibuk untuk pemain sepakbola profesional di akhirakhir musim kompetisi, apalagi klub-klub yang bermain di beberapa kompetisi yang berbeda dengan jadwal yang cukup padat dan level permainan kompetisi tinggi.

Harus dicatat bahwa kadar $25(\mathrm{OH}) \mathrm{D}_{3}$ pada bulan September yang sudah mulai mendekati musim dingin pemain liga Spanyol lebih rendah kadarnya $20 \%$ dibandingkan pemain di Liga Primer Inggris (Morton et al., 2012). Pada bulan Agustus dengan posisi derajat sinar matahari sama Bolland et al. (2007) mengatakan bahwa perbedaan kadar vitamin D yang lebih tinggi dapat diinterpretasikan dan dikorelasikan negatif terhadap jumlah lemak di dalam tubuh. Dimungkinkan sebab dari intensitas cahaya matahari yang mempengaruhi metabolisme di dalam tubuh pemain. Dari data-data diatas dapat disimpulkan bahwa pada pesepakbola Eropa pada musim dingin akan terjadi penurunan kadar vitamin D di dalam tubuh para pemain sepakbola profesional (baik di Spanyol maupun Inggris), perbedaan yang terjadi kemungkinan akibat dari kondisi geografis dari masing-masing negara maupun faktor-faktor lain yang menjadi variabel perancu seperti fasilitas untuk pemain dan pola makan. Tentunya dalam usaha mengantisipasinya (de-

Tabel 2. Kadar serum tulang vitamin $D$ dan variabel lain (nilai rata-rata \pm SD) pada pemain bola 2 dua periode yang berbeda (Aleksandra Kopeć et al., 2013).

\begin{tabular}{lccc}
\hline & September 2011 & April 2012 & Nilai p \\
\hline 25(OH)D3 $(\mathrm{ng} / \mathrm{ml})$ & $30.82 \pm 9.04$ & $24.96 \pm 9.91$ & 0.0003 \\
PTH $(\mathrm{pg} / \mathrm{ml})$ & $21.37 \pm 6.83$ & $25.37 \pm 7.95$ & 0.0062 \\
P1NP $(\mathrm{ng} / \mathrm{ml})$ & $81.78 \pm 30.24$ & $79.83 \pm 22.57$ & NS \\
OC $(\mathrm{ng} / \mathrm{ml})$ & $35.26 \pm 12.60$ & $33.00 \pm 9.05$ & NS \\
Beta - CTx $(\mathrm{ng} / \mathrm{ml})$ & $0.71 \pm 0.21$ & $0.68 \pm 0.22$ & NS \\
OC/beta - CTx & $50.97 \pm 15.04$ & $50.60 \pm 11.34$ & NS \\
Kalsium $(\mathrm{mmol} / \mathrm{l})$ & $2.55 \pm 0.08$ & $2.46 \pm 0.08$ & 0.0004 \\
\hline
\end{tabular}


fisiensi vitamin D) staf medis dari klub harus menyediakan ketersediaan vitamin $\mathrm{D}$ yang dapat diperoleh dari sumber alami atau olahan dalam bentuk kapsul maupun tablet untuk para pemain sepakbola profesional.

\section{SIMPULAN}

Vitamin D memainkan peranan penting di dalam metabolisme tulang dan fungsi normal dari sistem otot. Penyebab utama berkurangnya kadar vitamin $\mathrm{D}$ di dalam tubuh adalah karena kurangnya pemaparan terhadap sinar matahari dan kurangnya asupan makanan yang mengandung vitamin D. Pengaruh vitamin D di dalam banyak proses kehidupan dan fungsi organ menarik perhatian para ilmuwan untuk meneliti aplikasinya terhadap orang yang masih muda, sehat dan secara fisik aktif dalam hal ini adalah pesepakbola profesional. Penelitian sebelumnya menjelaskan terdapat hubungan vitamin D pada kerja otot rangka. Beberapa penelitian menunjukkan bahwa ada hubungan positif dari kadar vitamin D dalam tubuh dengan performa pemain sepakbola. Namun pada penelitian lain menunjukkan hal sebaliknya. Kekurangan vitamin D dilaporkan umum terjadi pada atlet sepakbola profesional di Inggris Raya, dan seantero Eropa, khususnya pada saat latihan/kompetisi berlangsung pada musim dingin Dalam hal ini penelitian lebih lanjut dan dengan skala yang lebih besar harus dilakukan agar diketahui efek yang spesifik dari kadar vitamin D yang dapat mempengaruhi dan memberikan manfaat kesehatan, khususnya untuk pemain sepakbola.

\section{DAFTAR PUSTAKA}

Aleksandra Kopeć, Krzysztof Solarz, Filip Majda, Małgorzata Słowińska-Lisowska, Marek Mędraś An Evaluation of the Levels of Vitamin D and Bone Turnover Markers After the Summer and Winter Periods in Polish Professional Soccer Players Journal of Human Kinetics volume 38/2013, 135-140

\section{DOI: 10.2478/hukin-2013-0053}

Angeline, M. E., Gee, A.O., Shindle, M., Warren, R.F. and Rodeo, S.A. (2013) The effects of vitamin deficiency in athletes. Am. J. Sports Med. 41, 461-464.

Aranow, C. (2011). Vitamin D and the immune system. Journal of Investigative Medicine, 59(6), 881-886.

Bikle, D. (2009). Nonclassic actions of vitamin D. The Journal of Clinical Endocrinology \& Metabolism, 94(1), 26-34. doi:10.1210/ jc.2008-1454.

Bischoff HA, Stähelin HB, Urscheler N, Ehrsam R, Vonthein R, Perrig-Chiello P, Tyndall A, Theiler R. Muscle strength in the elderly: its relation to vitamin D metabolites. Arch Phys Med Rehabil, 1999; 80: 54.

Bischoff-Ferrari, H.A., Dietrich, T., Orav, E.J., Hu, F.B., Zhang, Y., Karlson, E.W., and Dawson-Hughes, B. 2004. Higher 25-hydroxyvitamin D concentrations are associated with better lower-extremity function in both active and inactive persons aged $>$ or $=60$ y. Am. J. Clin. Nutr. 80(3): 752-758. PMID: 15321818.

Bolland MJ, Grey A, Cundy T, Reid IR. Defining vitamin D deficiency. N Z Med J, 2007; 120: U2760.

Broe, K.E., Chen, T.C., Weinberg, J., Bischoff-Ferrari, H.A., Holick, M.F., and Kiel, D.P. 2007. A higher dose of vitamin D reduces the risk of falls in nursing home residents: a randomized, multiple-dose study. J. Am. Geriatr. Soc. 55(2): 234-239. doi:10.1111/j. 1532-5415.2007.01048.x. PMID:17302660.

Chen, T.C., Chimeh, F., Lu, Z., Mathieu, J., Person, K.S., Zhang, A., et al. 2007. Factors that influence the cutaneous synthesis and dietary sources of vitamin D. Arch. Biochem. Biophys. 460(2): 213-217. doi:10.1016/j.abb.2006.12.017. PMID:17254541.

Close, G. L., Russell, J., Cobley, J. N., Owens, D. J., Wilson, G., Gregson, W., ... Morton, J. P. (2013). Assessment of vitamin D concentration in non-supplemented professional athletes and healthy adults during the winter months in the UK: Implications for skeletal muscle function. Journal of Sports Sciences, 31(4), 344-353. doi:10.1080/02640414.2012.7 33822.

Czuba M, Maszczyk A, Gerasimuk D, Roczniok R, FidosCzuba O, Zając A, Gołaś A, Mostowik A, Langfort J. The effects of hypobaric hypoxia on erythropoiesis, maximal oxygen uptake and energy cost of exercise under normoxia in elite biathletes. J Sports Sci Medic, 2014; 13(4): 912-920.

Farrokhyar F, Tabasinejad R, Dao D, Peterson D, Ayeni OR, Hadioonzadeh R, Bhandari M. Prevalence of vitamin $\mathrm{D}$ inadequacy in athletes: a systematicreview and meta-analysis. Sports Med (Auckland, N.Z.), 2015; 45(3): 365-78. http://doi.org/10.1007/ s40279-014-0267-6 